\title{
TLR4 activation induces IL- $1 \beta$ release via an IPAF dependent but caspase 1/11/8 independent pathway in the lung
}

Suffwan Eltom ${ }^{1}$, Maria G Belvisi ${ }^{1}$, Liang Yew-Booth ${ }^{1}$, Bilel Dekkak${ }^{1}$, Sarah A Maher ${ }^{1}$, Eric D Dubuis ${ }^{1}$, Victoria Jones ${ }^{1}$, Kate A Fitzgerald ${ }^{2}$ and Mark A Birrell ${ }^{1^{*}}$

\begin{abstract}
Background: The IL-1 family of cytokines is known to play an important role in inflammation therefore understanding the mechanism by which they are produced is paramount. Despite the recent plethora of publications dedicated to the study of these cytokines, the mechanism by which they are produced in the airway following endotoxin, Lipopolysaccharide (LPS), exposure is currently unclear. The aim was to determine the mechanism by which the IL-1 cytokines are produced after LPS inhaled challenge.
\end{abstract}

Methods: Mice were challenged with aerosolised LPS, and lung tissue and bronchiolar lavage fluid (BALF) collected. Targets were measured at the mRNA and protein level; caspase activity was determined using specific assays.

Results: BALF IL-1b/IL-18, but not IL-1a, was dependent on Ice Protease-Activating Factor (IPAF), and to a lesser extent Apoptosis-associated Speck-like protein containing a CARD (ASC). Interestingly, although we measured an increase in mRNA expression for caspase 1 and 11, we could not detect an increase in lung enzyme activity or a role for them in IL-1a/b production. Further investigations showed that whilst we could detect an increase in caspase 8 activity at later points in the time course (during resolution of inflammation), it appeared to play no role in the production of IL-1 cytokines in this model system.

Conclusions: TLR4 activation increases levels of BALF IL-1b/LL-18 via an IPAF dependent and caspase 1/11/8 independent pathway. Furthermore, it would appear that the presence of IL-1a in the BALF is independent of these pathways. This novel data sheds light on innate signalling pathways in the lung that control the production of these key inflammatory cytokines.

Keywords: TLR4, IPAF, ASC, IL-1 release

\section{Background}

The IL-1 family of cytokines are known to possess potent pro-inflammatory properties $[1,2]$ and controlling their production and release is vital to maintaining a healthy lung $[3,4]$. The family contains IL- $1 \alpha$ and IL- $1 \beta$, which both activate the same receptor, IL-1R, [5] and IL-18 which activates the IL-18R [6,7]. All three cytokines are transcribed into pro-forms and, whereas pro-IL- $1 \alpha$ is biologically active, pro-IL- $1 \beta$ and pro-IL-18 require

\footnotetext{
* Correspondence: m.birrell@imperial.ac.uk

${ }^{1}$ Respiratory Pharmacology, National Heart and Lung Institute, Faculty of Medicine, Imperial College London, Exhibition Road, London SW7 2AZ, UK Full list of author information is available at the end of the article
}

cleaving into their mature forms [8-11]. The production of mature, active forms of IL-1 $\beta$ and IL-18 in many scenarios is thought to involve a 2 step process: firstly the transcription and translation of the pro-forms via a stimulus such as a TLR agonist (i.e. LPS on TLR4) and then a second stimulus that triggers the cleavage and subsequent release of the mature form (i.e. ATP activating $\mathrm{P}_{2} \mathrm{X}_{7}$ receptors) [12-16]. Pro-IL-1 $\beta$ and pro-IL-18, and not Pro-IL-1 $\alpha$, can be cleaved into mature forms by caspase 1 [17]. Mature caspase 1 itself is activated/ cleaved from the inactive pro-form [17]. This could be auto-processing [18] or via the actions of other kinases 
such as caspase 4 (or its murine homolog, caspase 11) [19]. Caspase-11 does not process pro-IL-1 $\beta$ directly [20].

Depending on the stimulus and the conditions, caspase 1 can be recruited into a protein complex known as the inflammasome which can include NALP3 (or NLRP3, PYPAF1, CIAS1), AIM2, IPAF (or NLRC4, TMS1) and ASC $[17,21,22]$. ASC is an adaptor molecule that is required in some instances to achieve partial or total activity of the inflammasome [23]. The key proteins central to IL-1 $\beta /$ IL-18 maturation depends on the stimulus and conditions [24-26]. IL-1 $\beta$ and IL-18 have also been shown to be released via caspase 1 independent mechanisms [27-29]. Recently evidence has been published to suggest caspase 8 can be involved in IL-1 $\beta$ maturation [30]. Furthermore, in some circumstances it is thought that the pro-forms are released and then cleaved into the mature form by a range of enzymes including fungal pathogens [31]; neutrophil proteinase-3 (PR3) [32,33]; mast cell chymase [34]; matrix metalloproteinases [35]; Cathepsin G [36] and a range of proteases including granzyme A elastase $[10,37,38]$.

Despite the recent plethora of publications dedicated to the study of the IL-1 family of cytokines, the mechanism by which they are produced in the airway after endotoxin (LPS) exposure is currently unclear. Typically experiments which investigate this signalling pathway and the production of IL-1 $\beta$ family cytokines involve the administration of lethal doses of LPS and the production of systemic cytokines. However, it could be argued that more moderate levels of LPS exposure, not resulting in lethality, are more clinically relevant. Indeed, these more moderate experimental protocols are known to result in measurable levels of IL-1 $\beta$ in the mouse, rat and human airway [39-43]. The aim of this study was to determine the mechanism by which the IL-1 family members are produced following after inhalation of the bacterial mimetic LPS in a murine model.

\section{Materials and methods \\ Mice}

All in vivo protocols were approved by Imperial College London ethical review process committee and we strictly adhered to the Animals (Scientific Procedures) Act 1986 UK Home Office guidelines. Experiments were performed under a Home office project licence (PPL 70/7212). Male C57bl/6 mice (18-24 g) were originally obtained from Harlan UK Limited (Bicester, UK) and bred in-house; food and water supplied ad libitum. Genetically modified mice (knockout, KOs) were back crossed at least 8 times and bred alongside the wild type mice: TLR4 -/-, Myd 88 -/-, $\mathrm{P}_{2} \mathrm{X}_{7}-/-$, ASC -/-, NALP3 -/-, IPAF -/- IL-1 $\beta-/-$, IL-18 -/-, caspase $1-/-$ and caspase $11-/-$. Recently it has been established that due to the way they were originally engineered, the caspase $1 \mathrm{KO}$ mice are also deficient in caspase 11 [44]. The KO mice were donated from various laboratories: $\mathrm{P}_{2} \mathrm{X}_{7}$ from Professor Jean Kanellopoulos from University Paris-Sud; Myd 88 $-/-$, TLR4 -/- and caspase $1-/-$ from the Swiss Immunological Mouse Repository (SwImMR); IL-1b -/from Professor Yoichiro Iwakura from the University of Tokyo, IL-18 -/- were from Jackson labs, USA; ASC -/-, NALP3 -/-, and IPAF -/- from Professor Kate Fitzgerald (via Professor Clare Bryant, Cambridge University), University of Massachusetts Medical School and caspase 11 -/- from Professor Dixit, Genentech, USA.

\section{Model system}

Mice were challenged with aerosolised saline or submaximal LPS $(1 \mathrm{mg} / \mathrm{ml}$, Escherichia coli serotype 0111:B4 from Sigma, UK [39]) in a perspex box for 30 minutes.

\section{Time course study}

Wild type mice were culled with an overdose of pentobarbitone (Merial, France, $200 \mathrm{mg} / \mathrm{kg}$, i.p.) at 2, 6, 24, 72 96 and 168 hours after the end of the challenge. Tail tips were harvested and kept at $-20^{\circ} \mathrm{C}$ for possible future genotype confirmation. The trachea was cannulated (Teflon precision dispensing tips, From Adhesive dispensers Ltd, UK) and then lavaged with $0.3 \mathrm{ml}$ RPMI 1640 (Invitrogen, UK) three times, and the lavage fluid pooled. The chest was opened and the lung tissue removed, cleaned and flash frozen in liquid nitrogen. The lavage fluid was centrifuged at $900 \mathrm{~g}$ at $4^{\circ} \mathrm{C}$ for 10 minutes and the supernatant retained for cytokine measurement. The cytokines were measured either by Meso Scale Discovery (MSD, USA) technology or using specific ELISAs from R\&D systems, UK.

Gene expression levels were measured according to a method we have previously described (McCluskie et al., 2004). Briefly, RNA was extracted with TRI reagent (Sigma, UK) and samples were reverse transcribed using a master mix (Applied Biosystems, UK) in a PerkinElmer 480 thermal cycler (PerkinElmer Life and Analytical Sciences, USA). Transcriptional expression of target mRNA transcripts in RNA samples were detected by TaqMan real-time quantitative polymerase chain reaction (PCR) with the ABI PRISM 7000 Sequence Detection System (Applied Biosystems, UK). Fluorescentlabelled TaqMan probes for target genes were purchased from Applied Biosystems (UK). Reactions were internally controlled with the 18S rRNA internal control (Applied Biosystems, UK) and performed as multiplex reactions. Validations were performed to ensure the reactions were efficient. Caspase 1 and 8 activity in the lung tissue was measured using specific commercially available assays. The caspase 1 assay and data is presented by Eltom et al. [39]. For caspase 8 activity, the same lung tissue 
cytosolic fractions were assessed using a Caspase-Glo 8 Assay (Promega, UK) according to the manufacturer's instructions.

\section{Investigative studies}

Wild type or GM mice were challenged with vehicle or LPS (as above) and cytokine profile determined. In some cases, target mRNA expression levels and caspase activity was assessed.

\section{Results}

Time course for LPS driven response: IL-1 family and associated machinery

Inhaled LPS caused a temporal increase in IL- $1 \alpha$, IL- $1 \beta$, IL-1R and IL-18R, but surprisingly not IL-18, mRNA in mouse lung tissue (Figure 1). Indeed, it would appear at the 24 hour time point there was a decrease in expression of IL-18 mRNA. Measurement of BALF levels of the same cytokines revealed that all three cytokines are increased after LPS challenge compared to vehicle challenged, time matched control (Figure 2). Measurement of the machinery that is reported to be associated with the release of the IL-1 family of cytokines showed no change in IPAF mRNA, a transient decrease in $\mathrm{P}_{2} \mathrm{X}_{7}$ receptor mRNA, and increases in ASC, NALP3, caspase 1 and caspase 11 mRNA expression compared to lungs from time-matched, control treated mice (Figures 3 and 4).

\section{The role of TLR4 and Myd88 in LPS responses}

Compared to wild type, age matched controls; the response to inhaled LPS was completely attenuated in mice missing functional TLR4 and Myd88 as expected.
Levels of NALP3, caspase 11, IL- $1 \alpha$ and IL- $1 \beta$ were increased 6 hours after LPS challenge in wild type mice and not in the $\mathrm{KO}$ mice indicating that the response observed is dependent on TLR4 and Myd88 (Figure 5). Parallel data was obtained when cytokine protein levels were assessed in the BALF (data not shown).

\section{Mechanism of cytokine release following LPS challenge}

As discussed above, the $\mathrm{P}^{2} \mathrm{X}_{7}$ receptor has been linked to the release of IL-1 family cytokines in configured cell based assays. The LPS challenge caused a statistically significant increase in IL-1 cytokines in the wild type mice (Figure 6). The levels of IL- $1 \alpha$ and IL-1 $1 \beta 6$ hours after challenge were not altered in the $\mathrm{P}_{2} \mathrm{X}_{7} \mathrm{KO}$ mice; the level of IL-18 did appear to be reduced, although this did not reach statistical significance (Figure 6).

The inflammasome proteins have been associated with processing and release of IL-1 family cytokines. Indeed results from the time course showed that mRNA levels of the NOD-like receptor NALP3 and adaptor molecule ASC were increased in the lung tissue after LPS challenge suggestive of a role in this process. However, data from a study in which we compared the levels of IL-1 cytokines in wild type mice to those measured in mouse lines missing key inflammasome proteins, showed that IL- $1 \beta$ and IL-18 levels were decreased in the IPAF and ASC KO mice but interestingly not the NALP3 KO mice (Figure 7). The levels of IL- $1 \alpha$ were not altered in any of the GM lines tested (Figure 7).

As discussed above, dogma suggests that IPAF and ASC are involved in the maturation of IL-1 cytokines. To examine this we measured the levels of IL-1 $\beta$ in the lung tissue from the study with the inflammasome $\mathrm{KO}$

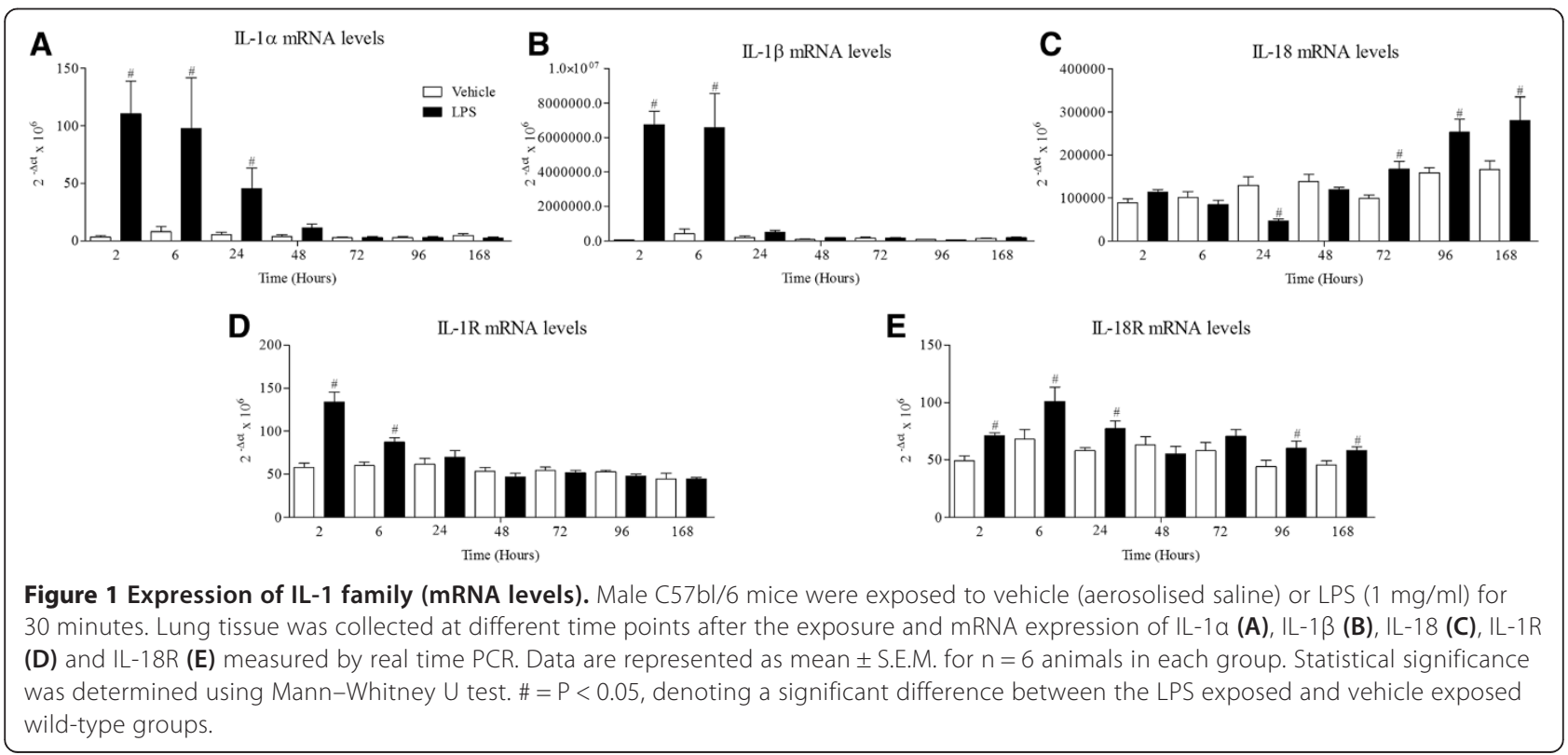



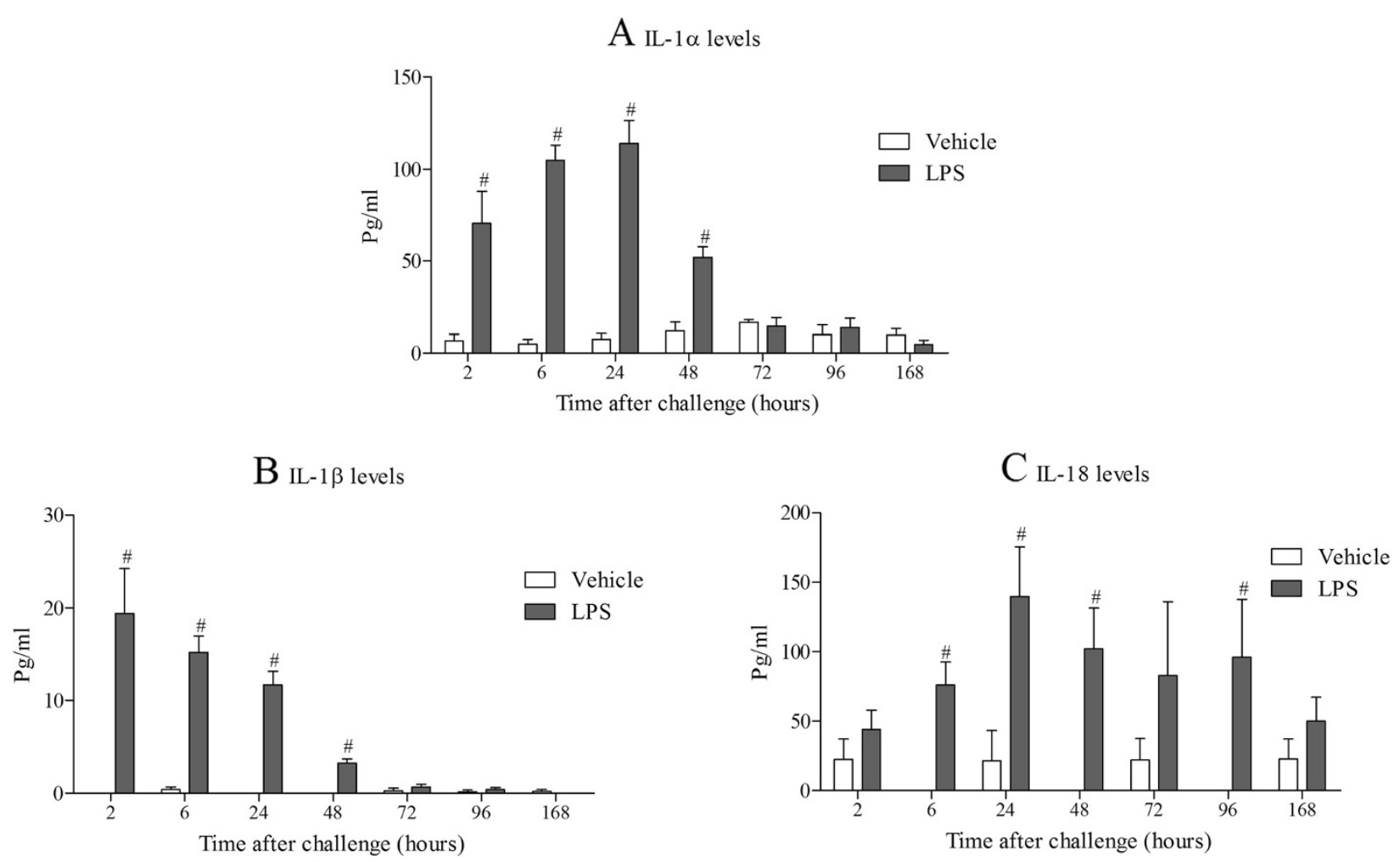

Figure 2 Expression of IL-1 family (protein levels). Male C57bl/6 mice were exposed to vehicle (aerosolised saline) or LPS (1 mg/ml) for 30 minutes. BALF was collected at different time points after the exposure and IL-1a (A), IL-1 $\beta$ (B) and IL-18 (C) measured by ELISA. Data are represented as mean \pm S.E.M. for $n=6$ animals in each group. Statistical significance was determined using Mann-Whitney $U$ test. \# $=P<0.05$, denoting a significant difference between the LPS exposed and vehicle exposed wild-type groups.

mice. As expected LPS challenge increased the mRNA level of IL-1 $\beta$ (4.4 to $64.42^{\wedge}$-dct $\left.\times 10^{6}\right)$, and this was not altered in the IPAF $\left(69.52^{\wedge}\right.$-dct $\left.\times 10^{6}\right) \mathrm{KO}$ mice.

Caspase 1 and 11 have been reported to be central to the maturation of IL-1 cytokines and have been linked to IPAF, thus we wanted to explore the role of these enzymes in our system. In these studies, LPS challenge caused a significant increase in IL-1 cytokines in the wild type mice. In the caspase $1 / 11$ and caspase $11 \mathrm{KO}$ mice the levels of BALF IL- $1 \alpha$ and IL- $1 \beta$ were not altered (Figure 8). In both GM lines the levels of IL-18 were reduced but this failed to reach statistical significance (Figure 8). There were no statistically significant differences in the cytokine levels of the vehicle challenged GM mice compared to wild type comparators (data not shown).

As it appeared that neither caspase 1 nor 11 were necessary for LPS induced IL-1 cytokines in the BALF, we studied the role of another caspase recently linked to the maturation and release of these cytokines, caspase 8 $[30,45,46]$. Caspase $8 \mathrm{KO}$ mice are embryonically lethal [47] and there are currently no selective caspase 8 inhibitors suitable for in vivo studies. Thus we decided to measure caspase 8 activity to investigate its role in LPS induced BALF IL-1 cytokine levels. In the lung samples from the time course study we could detect an increase in caspase 8 activity (Figure 9). The temporal increase in activity did not appear to correlate with the presence of IL-1 cytokines in the BAL but appeared to be associated with the resolution of the cellular inflammation suggesting the increase is related to apoptosis of the white cells. Further evidence for the lack of a role for caspase 8 in the production of IL-1 cytokines is suggested by the fact that caspase 8 activity was reduced in the IPAF KO mice (Figure 9B).

IL-1 $\beta$ and IL-18 have been suggested to be linked to the release of IL-1 $\alpha[48,49]$. To explore this in our model system we used IL- $1 \beta$ and IL-18 KO mice, with caspase $1 / 11 \mathrm{KOs}$ as negative controls. As expected the LPS challenge caused a significant increase in BALF IL- $1 \alpha$ which was, however, not altered in the $\mathrm{KO}$ mice (Figure 9C).

\section{Discussion}

The IL-1 family of cytokines are known to play an important inflammatory role in many biological processes 

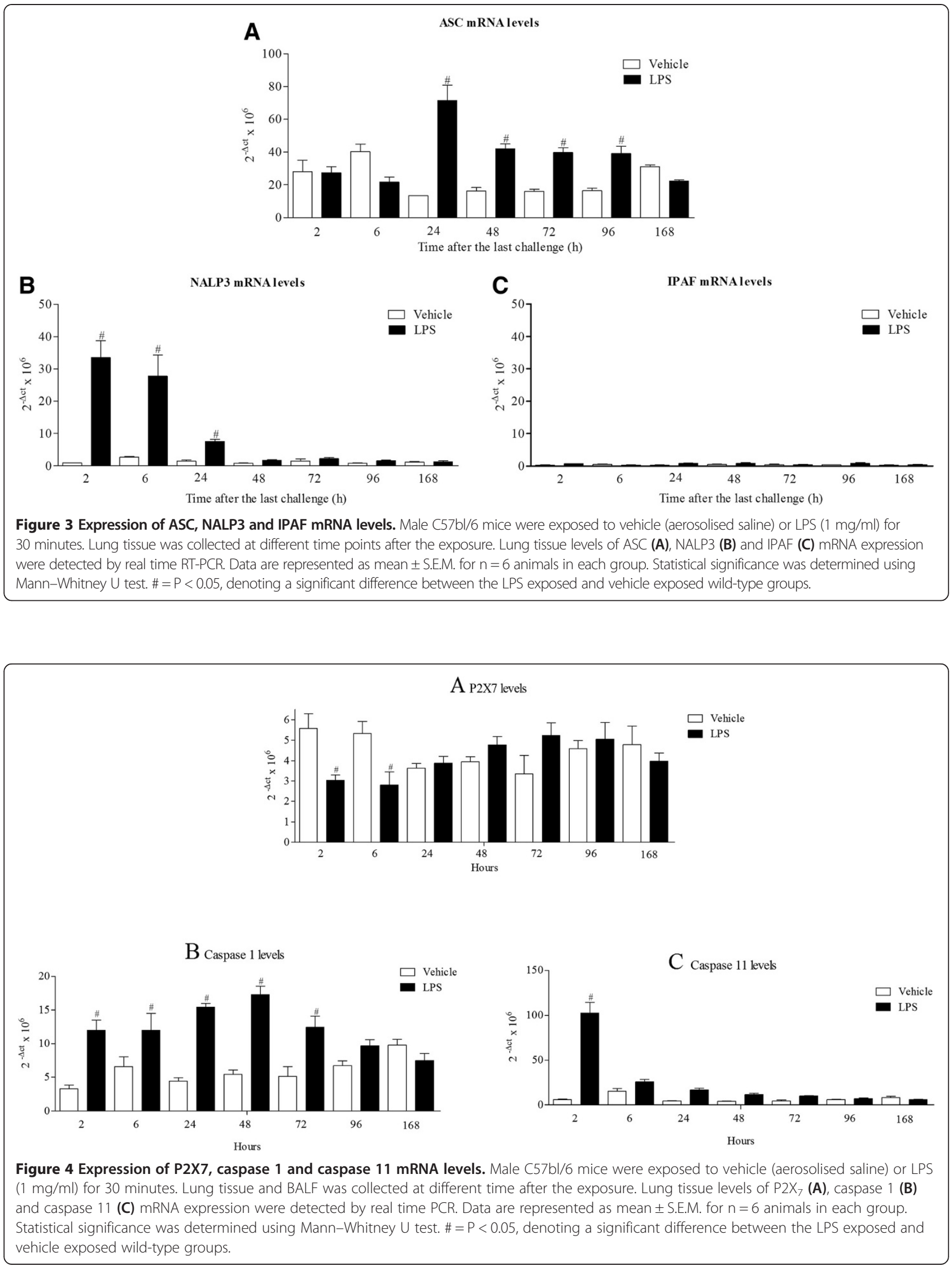


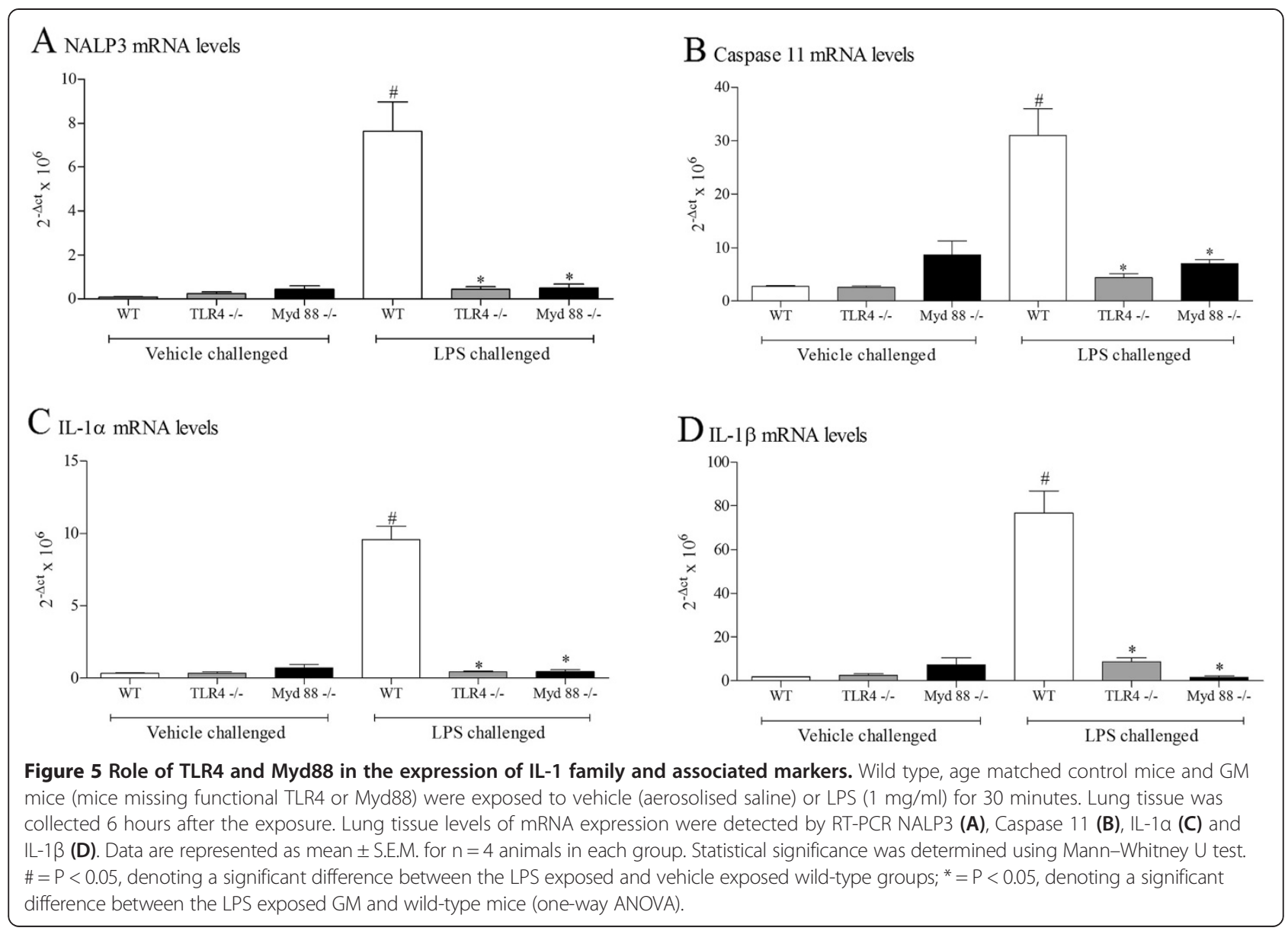

in the lung. Currently the mechanisms involved are unknown and understanding how these cytokines are produced is of paramount importance. Recently, research has focussed on the proposed 2 step process by which these cytokines are thought to be produced. In general the studies involve using configured cells grown from monocytes (i.e. blood) or harvested from body compartments (i.e. thioglycollate dosed peritoneal cavity, bone marrow) and when in vivo systems have been used often the end point used is death. However, it is well known that in the airway non-lethal, endotoxin challenge alone can cause the release of IL-1 cytokines in a range of species, including man [39-43]. Furthermore, LPS challenge models in man are becoming an increasingly popular investigative tool for new medications targeting COPD. Therefore, the aim of this study was to determine the mechanism by which the IL-1 family members are produced after activation of TLR4 by inhaled bacterial mimetic LPS.

In time course studies inhaled LPS triggered a rapid increase in IL- $1 \alpha$, IL- $1 \beta$ and IL-18 protein in the BALF but only increased IL- $1 \alpha$ and IL- $1 \beta$ mRNA levels in the lung tissue. This would suggest that unlike IL- $1 \alpha$ and $\beta$,
IL-18 is not induced transcriptionally in this model system. Indeed, there is a strong signal for IL-18 mRNA in unchallenged mouse lungs and at the 24 hour time point following LPS challenge there appeared to be a decrease in IL-18 mRNA. This could because the mRNA is being used to replenish the normal stored levels of pro-IL-18, something that has been suggested in other lung inflammation models [50]. When we studied the expression of the machinery reported to be involved in the release of IL-1 cytokines, we found that ASC, NALP3, caspase 1 and caspase 11 were increased at the mRNA level, whereas $\mathrm{P}_{2} \mathrm{X}_{7}$ receptor expression was transiently reduced and IPAF levels were below reliable detection limits. Whilst, as far as we are aware, these markers have not been comprehensively measured in the mouse lung after LPS challenge, there are reports of similar increases in cultured cell systems $[19,51]$. The decrease in $\mathrm{P} \mathrm{X}_{7}$ receptor mRNA expression is interesting. Previously a group has described an increase in $\mathrm{P}_{2} \mathrm{X}_{7}$ receptor protein expression in their mouse endotoxin challenge model, the difference could be down to the different experimental designs (i.e. dosing of LPS, timing of sampling) and measuring mRNA versus protein [52]. In addition, whilst 


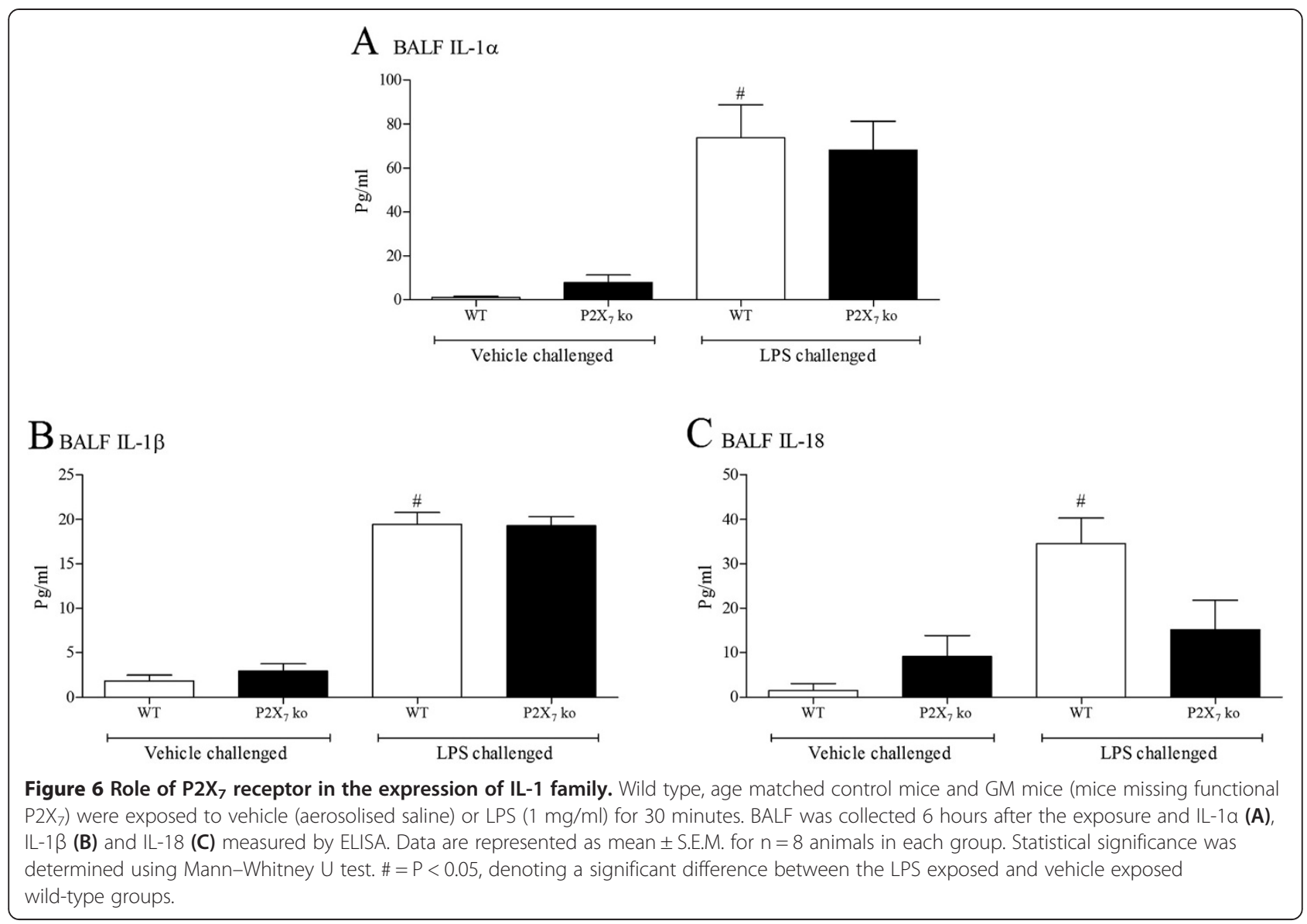

we did observe a transient reduction in $\mathrm{P}_{2} \mathrm{X}_{7}$ receptor mRNA expression, this may not be indicative of changes in protein levels and other factors like levels of ligands and signalling/coupling status are more likely to be biologically important. On balance the expression data suggests that the endotoxin challenge is priming the machinery known to be associated with the release of IL-1 cytokine in the airway. One caveat, however, that could be argued is that these mRNA expression changes are due to an altered cellular burden observed after LPS challenge [39].

To determine if the increased expression was dependent on TLR4 and a key protein in the signalling cascade, Myd88, we repeated the experiment in GM mice missing functional proteins. The data clearly showed that TLR4 and Myd88 are required for the LPS induced increase in NALP3, caspase 11, IL- $1 \alpha$ and IL-1 $\beta$ expression and whilst we cannot exclude the possibility that LPS enters the cell and directly interacts with proteins (similar to NODs), it seems likely that TLR4 and Myd88 play a crucial role in the response.

To begin to explore the mechanism by which IL-1 cytokines are released into the BAL, we explored the role of the $\mathrm{P} 2 \mathrm{X}_{7}$ receptor. Although in these studies we challenged with LPS alone it is possible that this receptor is being stimulated by endogenously produced stimuli (i.e. ATP) and that this triggers the second signal known to cause the maturation of IL-1 cytokines. Indeed Monção-Ribeiro et al. [52] found that mice missing functional $\mathrm{P} 2 \mathrm{X}_{7}$ had reduced levels of IL-1 $\beta$. In these studies $\mathrm{P} 2 \mathrm{X}_{7} \mathrm{KO}$ mice had similar levels of IL- $1 \alpha$ and IL-1 compared to age matched, wild type controls suggesting that endogenous $\mathrm{P}_{2} \mathrm{X}_{7}$ receptor activators are not produced in our model system. The reason for the discrepancy between data sets is not known but our data is in line with a previous finding that LPS challenge did not increase caspase 1 activity (a downstream marker of $\mathrm{P}_{2} \mathrm{X}_{7}$ receptor activation) [39]. Furthermore, we have detected an increase in BALF ATP levels in a smoke driven model [53], but no similar increase after LPS challenge (data not shown).

As discussed the IL-1 family of cytokines have been closely linked to inflammasome proteins; there are a range of publications linking the maturation and release of IL-1 cytokines to NALP3, ASC and IPAF. When we investigated their involvement in this system we found that although NALP3 expression was increased by LPS challenge, it was not necessary for the release of the IL-1 


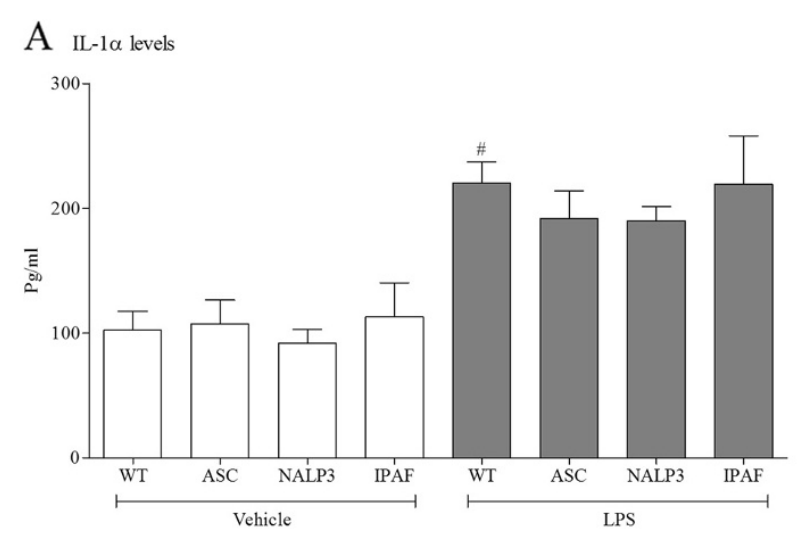

B IL-1ß levels

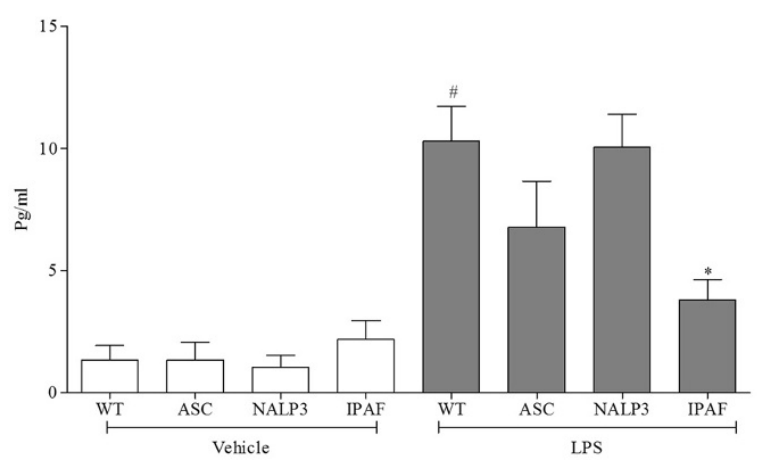

$\mathrm{C}_{\text {IL-18 levels }}$

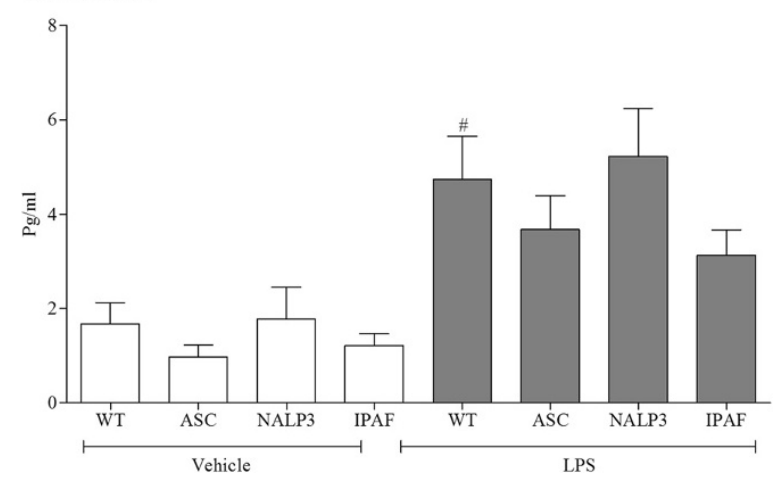

Figure 7 Role of the inflammasome in the expression of IL-1 family. Wild type, age matched control mice and GM mice (mice missing functional ASC, NALP3 and IPAF) were exposed to vehicle (aerosolised saline) or LPS (1 mg/ml) for 30 minutes. BALF was collected 6 hours after the exposure and IL-1a (A), IL-1B (B) and IL-18 (C) measured by ELISA. Data are represented as mean \pm S.E.M. for $n=8$ animals in each group. Statistical significance was determined using Mann-Whitney $U$ test. \# $=P<0.05$, denoting a significant difference between the LPS exposed and vehicle exposed wild-type groups; ${ }^{*}=\mathrm{P}<0.05$, denoting a significant difference between the LPS exposed GM and wild-type mice (one-way ANOVA).

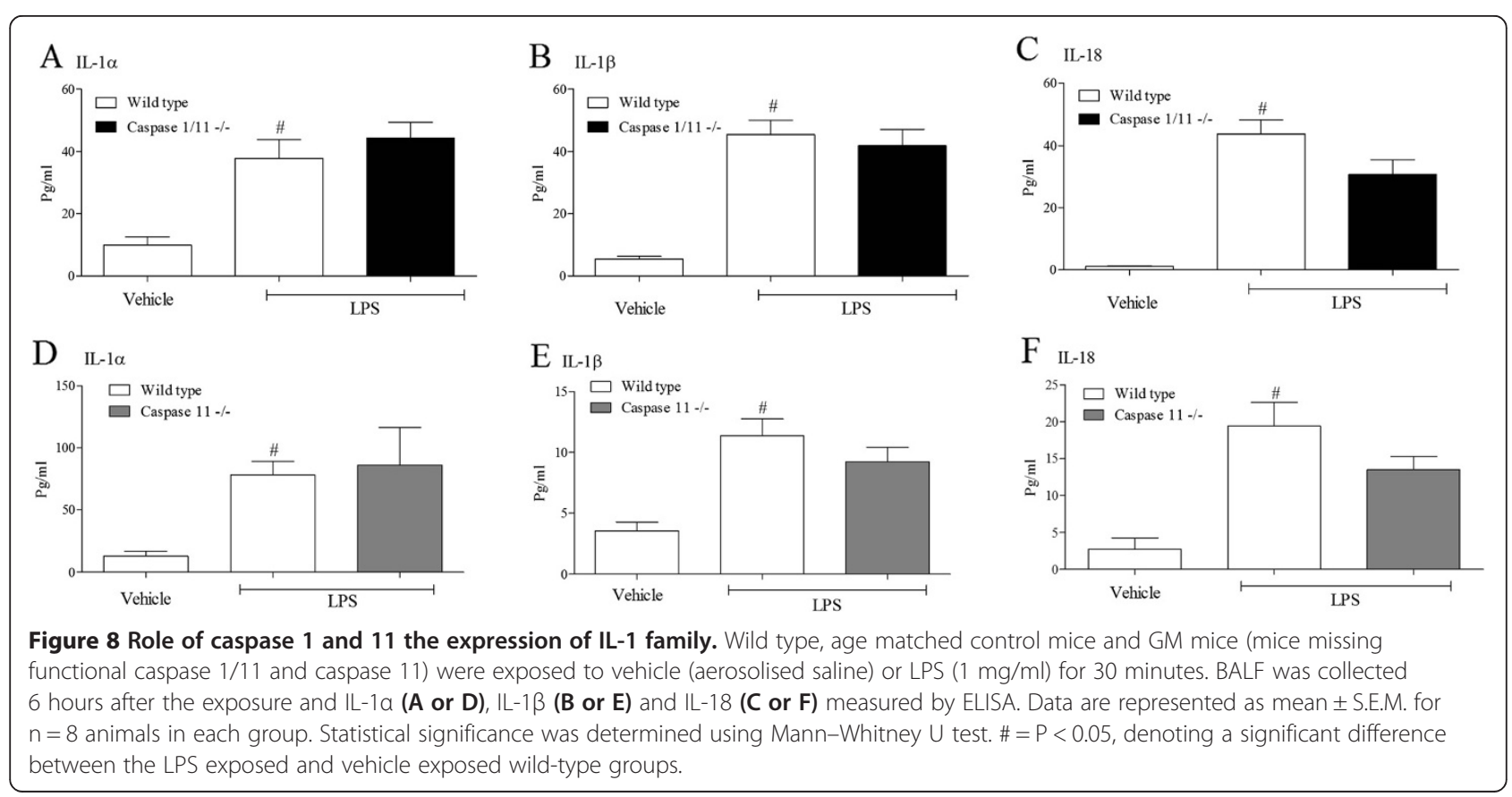




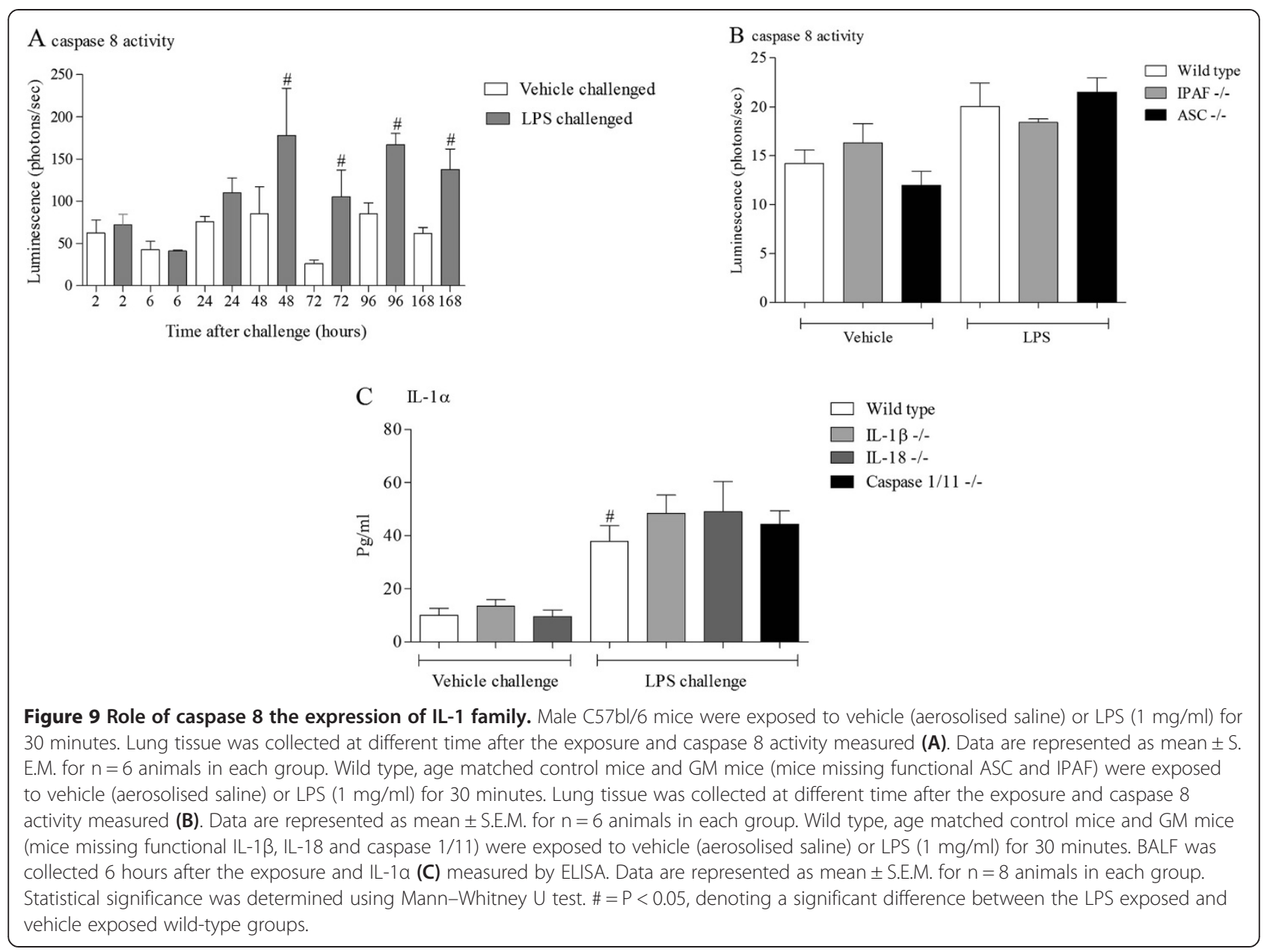

cytokines. IPAF, and to a lesser extent ASC, did appear to be required for IL-1 $\beta$ and IL-18, but interestingly not IL-1 $\alpha$. There are a number of reports that have, in general, have linked IPAF and ASC with mature IL-1 cytokine production in a caspase-dependent manner [54-57]. However, although we measured an increase in caspase 1, and its reported activator [44] caspase 11, surprisingly the caspase $1 / 11$ or caspase $11 \mathrm{KO}$ mice did not have reduced IL-1 cytokines. Whilst caspase 11 is not thought to process pro-IL- $1 \beta$ directly, it has been reported to cleave pro-caspase 1 into the mature active form and it has also been linked to the release of IL-1 $\alpha[19,20]$. This data led us to the conclusion that the release of IL-1 cytokines was either dependent on another caspase or was independent of caspase enzyme activity. Recently it has been reported that caspase 8 can cleave pro-IL-1 $\beta$ [30]. We could not adopt our normal strategy and employ GM mice because blocking caspase 8 activity results in embryonic lethality [47] and as yet there are no selective pharmacological inhibitors with the correct profile for in vivo use. Thus we utilised the specific activity assay to look for an increase in caspase 8 activity and to determine if it was decreased in the IPAF KO mice (on the assumption that IPAF would be upstream of caspase 8). Whilst we did detect an increase in caspase 8 activity in the lung tissue, it appeared to temporally correlate with the resolution of the inflammation (i.e. associated with apoptosis) and any increase observed at the time points we measured IL-1 cytokines was not altered in the IPAF KOs. Together this data would suggest that the IL-1 $\beta$ and IL-18 measured in the BALF was dependent on IPAF but independent of caspase 1, 8 and 11 and would imply that other mechanisms are involved in the maturation of these cytokines as discussed previously. One candidate would be the matrix metalloproteinases [35] and we have previously reported that there is an increase in MMPs in the lung after LPS challenge [58]. However, data from a study in which we used a pan MMP inhibitor showed no change in IL-1 $\beta$ levels which would question this hypothesis [59].

Whilst we were able to determine that TLR4 and Myd88 were essential for LPS- induced IL- $1 \alpha$ production in the BALF, we were unable to delineate further down 


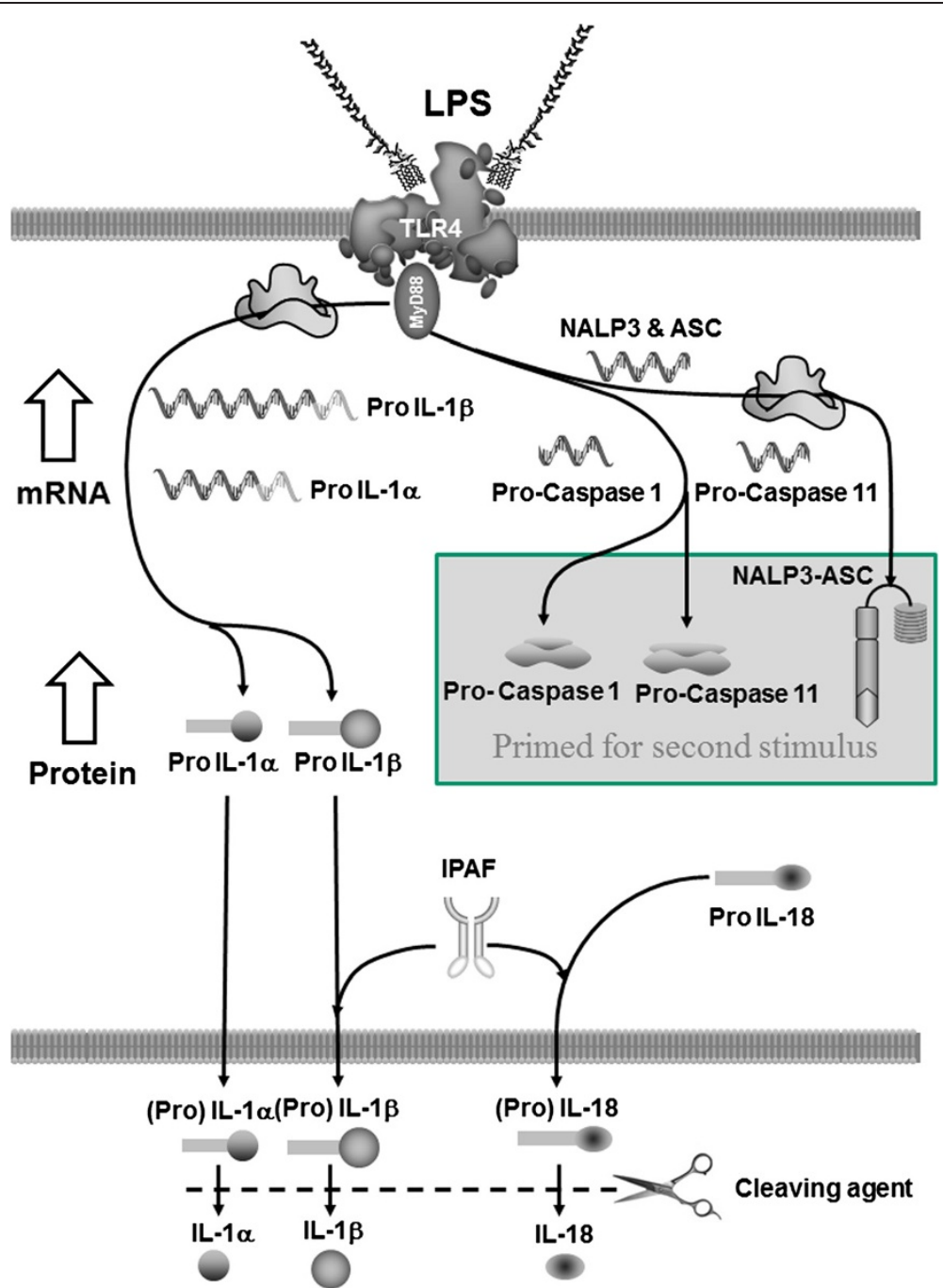

Figure 10 Schematic representative of the in vivo data. Our data suggests that in the mouse inhaled LPS activates TLR4 in the airway to trigger MyD88 dependent increase mRNA production of pro-IL-1a, pro-IL-1ß, pro-Caspase 1, pro-caspase 11, ASC and NALP3, but not pro-IL-18 or IPAF. These increases in mRNA levels are likely to be associated with an increase in the corresponding protein levels. The pro-Caspase 1, pro-caspase 11, ASC and NALP3 are then primed ready for a second stimulus (i.e. via ATP-P2X7) and subsequent processing of pro-IL-1 $\beta$ and pro-IL-18. The LPS stimulus causes caspase 1/caspase 11 independent release of $\mathrm{IL}-1 \mathrm{a}, \mathrm{IL}-1 \beta$ and IL-18 into the airway lumen (either in the pro or mature form), of which the latter two appear to require IPAF. Pro-forms of the cytokines could be cleaved to the mature forms outside the cell.

the pathway. Reports have suggested that other IL-1 family members can act as chaperones for IL- $1 \alpha$ but the data with IL- $1 \beta$ and IL-18 KO mice clearly showed that in this system this was not the case. Others have suggested that members of the calpain family of proteases are involved $[60,61]$ whereas recently Lukens et al. [62] have reported that RIP1 driven auto-inflammation targets IL- $1 \alpha$ independently of the inflammasome. Further, investigation is required to determine the mechanism by which LPS induces an increase in BALF IL- $1 \alpha$ after LPS.

In conclusion, the data suggests that activation of TLR4 increases levels of BALF IL- $1 \beta$ and IL-18 via an IPAF dependent and caspase 1/11/8 independent pathway. We have attempted to capture this in a schematic
(Figure 10). Furthermore, it would appear that IL-1 $\alpha$ is produced via a different mechanism. These are important, novel findings that further our understanding of this prominent family of inflammatory cytokines in the lung and their role in the innate immune system.

\section{Competing interest}

The authors declare that they have no competing interests.

\section{Authors' contribution}

SE and MAB carried out the in vivo studies, LY-B, BD, SAM, EDD and VJ participated in the sample analysis. KAF generated the GM mice. SE, MGB and MAB conceived of the study, and participated in its design and coordination and helped to draft the manuscript. All authors read and approved the final manuscript. 


\section{Author details}

'Respiratory Pharmacology, National Heart and Lung Institute, Faculty of Medicine, Imperial College London, Exhibition Road, London SW7 2AZ, UK.

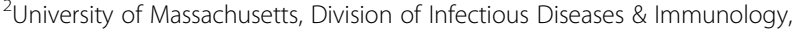
Worcester, MA 01605, USA.

Received: 7 April 2014 Accepted: 23 July 2014

Published: 2 August 2014

\section{References}

1. Dinarello CA: Interleukin-1. Cytokine Growth Factor Rev 1997, 8:253-265.

2. Van de Veerdonk FL, Netea MG: New Insights in the Immunobiology of IL-1 Family Members. Front Immunol 2013, 4(July):167.

3. Fantuzzi G, Dinarello CA: Interleukin-18 and interleukin-1 beta: two cytokine substrates for ICE (caspase-1). J Clin Invest 1999, 19:1-11.

4. Creagh EM, Conroy H, Martin SJ: Caspase-activation pathways in apoptosis and immunity. Immunol Rev 2003, 193:10-21.

5. Dinarello C, Wolff S: The role of interleukin-1 in disease. New Engl J 1993, 328:106-113.

6. Gracie JA, Robertson SE, McInnes IB: Interleukin-18. J Leukoc Biol 2003, 73(2):213-224.

7. Mühl H, Pfeilschifter J: Interleukin-18 bioactivity: a novel target for immunopharmacological anti-inflammatory intervention. Eur J Pharmacol 2004, 500:63-71.

8. Black RA, Kronheim SR, Cantrell M, Deeley MC, March CJ, Prickett KS, Wignall J, Conlon PJ, Cosman D, Hopp TP: Generation of biologically active interleukin-1 beta by proteolytic cleavage of the inactive precursor. J Biol Chem 1988, 263:9437-9442.

9. Jobling SA, Auron PE, Gurka G, Webb AC, Mcdonald B, Rosenwasser L, Gehrke L: Biological activity and receptor binding of human prointerleukin-1 beta and subpeptides. J Biol Chem 1988, 263(31):16372-16378.

10. Matsushima K, Taguchi M, Kovacs EJ, Young HA, Oppenheim JJ: Intracellular localization of human monocyte associated interleukin 1 (IL 1) activity and release of biologically active IL 1 from monocytes by trypsin and plasmin. J Immunol 1986, 136:2883-2891.

11. Mosley B, Urdal DL, Prickett KS: The interleukin-1 receptor binds the human interleukin-1 alpha precursor but not the interleukin-1 beta precursor. J Biol 1987, 262:2941-2944.

12. Perregaux D, Gabels A: Interleukin-IP Maturation and Release in Response to ATP and Nigericin; 1994.

13. Hogquist KA, Unanue ER, Chaplin DD: Release of IL-1 from mononuclear phagocytes. J Immunol 1991, 147:2181-6.

14. Ferrari D, Chiozzi P: Extracellular ATP triggers IL-1 beta release by activating the purinergic $\mathrm{P} 2 \mathrm{Z}$ receptor of human macrophages. J Immunol 1997, 159:1451-1458.

15. Perregaux DG, McNiff $P$, Laliberte $R$, Conklyn M, Gabel CA: ATP acts as an agonist to promote stimulus-induced secretion of IL-1 beta and IL-18 in human blood. J Immunol 2000, 165:4615-4623.

16. Surprenant A, Rassendren F, Kawashima E, North RA, Buell G: The cytolytic P2Z receptor for extracellular ATP identified as a P2X receptor (P2X7). Science 1996, 272(5262):735-738.

17. Martinon F, Tschopp J: Inflammatory caspases: linking an intracellular innate immune system to autoinflammatory diseases. Cell 2004, 117:561-574.

18. Ayala J, Yamin T, Egger L: IL-1 beta-converting enzyme is present in monocytic cells as an inactive 45-kDa precursor. J Immunol 1994, 153:2592-2599.

19. Wang S, Miura M, Jung YK, Zhu H, Li E, Yuan J: Murine caspase-11, an ICE-interacting protease, is essential for the activation of ICE. Cell 1998, 92:501-509.

20. Miura M, Wang S, Jung YK, Gagliardini V, Greenberg AH, Miura M, Zhu H, Shi LYJ: Identification and Characterization of Ich-3, a Member of the Interleukin-1 beta Converting Enzyme (ICE)/Ced-3 Family and an Upstream Regulator of ICE. J Biol Chem 1996, 271:20580-20587.

21. Schroder K, Tschopp J: The inflammasomes. Cell 2010, 140:821-832.

22. Latz E, Xiao TS, Stutz A: Activation and regulation of the inflammasomes. Nat Rev Immunol 2013, 13:397-411.

23. Taniguchi S, Sagara J: Regulatory molecules involved in inflammasome formation with special reference to a key mediator protein, ASC. Semin Immunopathol 2007, 29:231-238.
24. Damiano JS, Stehlik C, Pio F, Godzik A, Reed JC: CLAN, a novel human CED-4-like gene. Genomics 2001, 75:77-83.

25. Dowds TA, Masumoto J, Zhu L, Inohara N, Núñez G: Cryopyrin-induced interleukin 1 beta secretion in monocytic cells: enhanced activity of disease-associated mutants and requirement for ASC. J Biol Chem 2004, 279:21924-21928.

26. Mariathasan S, Weiss DS, Newton K, McBride J, O'Rourke K, Roose-Girma M, Lee WP, Weinrauch Y, Monack DM, Dixit VM: Cryopyrin activates the inflammasome in response to toxins and ATP. Nature 2006, 440:228-32.

27. Mehta VB, Hart J, Wewers MD: ATP-stimulated release of interleukin (IL)- 1 beta and IL-18 requires priming by lipopolysaccharide and is independent of caspase-1 cleavage. J Biol Chem 2001, 276:3820-3826.

28. Wewers $\mathrm{M}$, Dare H: IL-1 beta-converting enzyme (ICE) is present and functional in human alveolar macrophages: macrophage IL-1 beta release limitation is ICE independent. J Immunol 1997, 159:5964-5972.

29. Ikawa K, Nishioka T, Yu Z, Sugawara Y, Kawagoe J, Takizawa T, Primo V, Nikolic B, Kuroishi T, Sasano T, Shimauchi H, Takada H, Endo Y, Sugawara S: Involvement of neutrophil recruitment and proteaseactivated receptor 2 activation in the induction of IL-18 in mice. J Leukoc Biol 2005, 78(5):1118-1126.

30. Maelfait J, Vercammen E, Janssens S, Schotte P, Haegman M, Magez S, Beyaert R: Stimulation of Toll-like receptor 3 and 4 induces interleukin-1beta maturation by caspase-8. J Exp Med 2008, 205:1967-1973.

31. Beauséjour A, Grenier D, Goulet JP, Deslauriers N: Proteolytic activation of the IL-1b precursor by Candida albicans. Infect Immun 1998, 66(2):676-681.

32. Coeshott C, Pilyavskaya A, Wieczorek M, Leimer AH, Ohnemus C, Ross S, Kroona $\mathrm{HCJ}$ : Converting enzyme-independent release of tumor necrosis factor alpha and IL-1b from a stimulated human monocytic cell line in the presence of activated neutrophils or purified proteinase 3. Proc Am Thorac Soc 1999, 96:6261-6266.

33. Puren AJ, Fantuzzi G, Dinarello CA: Gene expression, synthesis, and secretion of interleukin 18 and interleukin 1beta are differentially regulated in human blood mononuclear cells and mouse spleen cells. Proc Natl Acad Sci U S A 1999, 96:2256-2261.

34. Mizutani $\mathrm{H}$, Schechter N: Rapid and specific conversion of precursor interleukin 1 beta (IL-1 beta) to an active IL-1 species by human mast cell chymase. J Exp Med 1991, 174(October):821-825.

35. Schönbeck U, Mach F, Libby P: Generation of biologically active IL-1 beta by matrix metalloproteinases: a novel caspase-1-independent pathway of IL-1 beta processing. J Immunol 1998, 161:3340-3346.

36. Hazuda D, Lee J, Young P: The kinetics of interleukin 1 secretion from activated monocytes. Differences between interleukin 1 alpha and interleukin 1 beta. J Biol Chem 1988, 263:8473-8479.

37. Dinarello CA, Cannon JG, Mier JW, Bernheim HA, LoPreste G, Lynn DL, Love RN, Webb AC, Auron PE, Reuben RC: Multiple biological activities of human recombinant interleukin 1. J Clin Invest 1986, 77:1734-1739.

38. Knudsen P: Purification and characterization of a unique human interleukin 1 from the tumor cell line U937. J Immunol 1986, 136:3311-3316.

39. Eltom S, Stevenson CS, Rastrick J, Dale N, Raemdonck K, Wong S, Catley MC Belvisi MG, Birrell MA: P2X7 receptor and caspase 1 activation are central to airway inflammation observed after exposure to tobacco smoke. PLoS One 2011, 6:e24097-e24097.

40. Liu Z, Yang Z, Fu Y, Li F, Liang D, Zhou E, Song X, Zhang W, Zhang X, Cao $Y$, Zhang N: Protective effect of gossypol on lipopolysaccharide-induced acute lung injury in mice. Inflamm Res 2013, 62:499-506.

41. Haddad EB, Birrell M, McCluskie K, Ling A, Webber SE, Foster ML, Belvisi MG: Role of p38 MAP kinase in LPS-induced airway inflammation in the rat. Br J Pharmacol 2001, 132:1715-1724.

42. Choi JS, Lee HS, Seo KH, Na JO, Kim YH, Uh ST, Park CS, Oh MH, Lee SH, Kim YT: The effect of post-treatment $\mathrm{N}$-acetylcysteine in LPS-induced acute lung injury of rats. Tuberc Respir Dis (Seoul) 2012, 73:22-31.

43. Eltom S, Nicole D, Kristof RG R, Stevenson CS, Snelgrove RJ, Chiara R, Silene W-S, McAuley DF, Cecilia O'K, Fitzgerald MGBMAB KA: A role for Extracellular vesicles and the P2X7-inflammasome axis in exacerbations of COPD and Asthma? 2013

44. Kayagaki N, Warming S, Lamkanfi M, Vande Walle L, Louie S, Dong J, Newton K, Qu Y, Liu J, Heldens S, Zhang J, Lee WP, Roose-Girma M, Dixit VM: Non-canonical inflammasome activation targets caspase-11. Nature 2011, 479:117-121

45. Vince JE, Wong WW-L, Gentle I, Lawlor KE, Allam R, O'Reilly L, Mason K, Gross O, Ma S, Guarda G, Anderton H, Castillo R, Häcker G, Silke J, Tschopp J: Inhibitor 
of apoptosis proteins limit RIP3 kinase-dependent interleukin-1 activation. Immunity 2012, 36:215-227.

46. Bossaller L, Chiang P-I, Schmidt-Lauber C, Ganesan S, Kaiser WJ, Rathinam VAK, Mocarski ES, Subramanian D, Green DR, Silverman N, Fitzgerald KA, Marshak-Rothstein A, Latz E: Cutting edge: FAS (CD95) mediates noncanonical IL-1 $\beta$ and IL-18 maturation via caspase-8 in an RIP3-independent manner. J Immunol 2012, 189:5508-5512.

47. Kaiser WJ, Upton JW, Long AB, Livingston-Rosanoff D, Daley-Bauer LP, Hakem R, Caspary T, Mocarski ES: RIP3 mediates the embryonic lethality of caspase-8-deficient mice. Nature 2011, 471:368-372.

48. Pauwels NS, Bracke KR, Dupont LL, Van Pottelberge GR, Provoost S, Vanden Berghe T, Vandenabeele P, Lambrecht BN, Joos GF, Brusselle GG: Role of IL-1a and the Nlrp3/caspase-1/LL-1 $\beta$ axis in cigarette smoke-induced pulmonary inflammation and COPD. Eur Respir J 2011, 38:1019-28.

49. Imaoka H, Hoshino T, Takei S, Kinoshita T, Okamoto M, Kawayama T, Kato S, Iwasaki H, Watanabe K, Aizawa H: Interleukin-18 production and pulmonary function in COPD. Eur Respir J 2008, 31:287-297.

50. Tran HB, Lewis MD, Tan LW, Lester SE, Baker LM, Ng J, Hamilton-Bruce MA, Hill CL, Koblar SA, Rischmueller M, Ruffin RE, Wormald PJ, Zalewski PD, Lang CJ: Immunolocalization of NLRP3 Inflammasome in Normal Murine Airway Epithelium and Changes following Induction of Ovalbumin-Induced Airway Inflammation. J Allergy 2012, 2012:819176.

51. Manji GA, Wang L, Geddes BJ, Brown M, Merriam S, Al-Garawi A, Mak S, Lora JM, Briskin M, Jurman M, Cao J, DiStefano PS, Bertin J: PYPAF1, a PYRIN-containing Apaf1-like protein that assembles with ASC and regulates activation of NF-kappa B. J Biol Chem 2002, 277:11570-11575.

52. Monção-Ribeiro LC, Cagido VR, Lima-Murad G, Santana PT, Riva DR, Borojevic R, Zin WA, Cavalcante MCM, Riça I, Brando-Lima AC, Takiya CM, Faffe DS, Coutinho-Silva R: Lipopolysaccharide-induced lung injury: role of P2X7 receptor. Respir Physiol Neurobiol 2011, 179:314-325.

53. Eltom S, Stevenson C, Birrell MA: Cigarette Smoke Exposure as a Model of Inflammation Associated with COPD. Curr Protoc Pharmacol 2013, 5:Unit5.64 doi: 10.1002/0471141755.ph0564s60.

54. Franchi L, Amer A, Body-Malapel M, Kanneganti T-D, Ozören N, Jagirdar R, Inohara N, Vandenabeele P, Bertin J, Coyle A, Grant EP, Núñez G: Cytosolic flagellin requires Ipaf for activation of caspase-1 and interleukin 1 beta in salmonella-infected macrophages. Nat Immunol 2006, 7:576-582.

55. Miao EA, Alpuche-Aranda CM, Dors M, Clark AE, Bader MW, Miller SI, Aderem A: Cytoplasmic flagellin activates caspase- 1 and secretion of interleukin 1 beta via Ipaf. Nat Immunol 2006, 7:569-575.

56. Amer A, Franchi L, Kanneganti T-D, Body-Malapel M, Ozören N, Brady G, Meshinchi S, Jagirdar R, Gewirtz A, Akira S, Núñez G: Regulation of Legionella phagosome maturation and infection through flagellin and host Ipaf. J Biol Chem 2006, 281:35217-35223.

57. Mariathasan S, Newton K, Monack DM, Vucic D, French DM, Lee WP, Roose-Girma M, Erickson S, Dixit VM: Differential activation of the inflammasome by caspase- 1 adaptors ASC and Ipaf. Nature 2004, 430:213-218.

58. Wong S, Belvisi MG, Birrell MA: MMP/TIMP expression profiles in distinct lung disease models: implications for possible future therapies. Respir Res 2009, 10:72.

59. Birrell MA, Wong S, Dekkak A, De AJ, Haj-yahia S, Belvisi MG: Role of Matrix Metalloproteinases in the Inflammatory Response in Human Airway Cell-Based Assays and in Rodent Models of Airway Disease. J Pharmacol Exp 2006, 318:741-750.

60. Carruth LM, Demczuk S, Mizel SB: Involvement of a calpain-like protease in the processing of the murine interleukin 1 alpha precursor. J Biol Chem 1991, 266:12162-12167.

61. Kobayashi Y, Yamamoto K, Saido T, Kawasaki H, Oppenheim JJ, Matsushima $\mathrm{K}$ : Identification of calcium-activated neutral protease as a processing enzyme of human interleukin 1 alpha. Proc Natl Acad Sci U S A 1990, 87:5548-5552.

62. Lukens JR, Vogel P, Johnson GR, Kelliher MA, Iwakura Y, Lamkanfi M, Kanneganti T-D: RIP1-driven autoinflammation targets IL-1a independently of inflammasomes and RIP3. Nature 2013, 498:224-227.

doi:10.1186/s12931-014-0087-0

Cite this article as: Eltom et al:: TLR4 activation induces IL- $1 \beta$ release via an IPAF dependent but caspase $1 / 11 / 8$ independent pathway in the lung. Respiratory Research 2014 15:87.

\section{Submit your next manuscript to BioMed Central and take full advantage of:}

- Convenient online submission

- Thorough peer review

- No space constraints or color figure charges

- Immediate publication on acceptance

- Inclusion in PubMed, CAS, Scopus and Google Scholar

- Research which is freely available for redistribution 